\title{
The Enhancement of Core Values and Competitiveness of Traditional Media Under the Impact of Emerging Media
}

\author{
Haotian Fan ${ }^{1, *}$ \\ ${ }^{1}$ Shanghai Rongyue Private Entry-Exit Services Co., Ltd, Shanghai 200052, China \\ *Corresponding author. Email:sost12822@163.com
}

\begin{abstract}
Under the impact of new media, some of the advantages of traditional media are slowly disappearing. If traditional media wants to occupy a place in the increasingly fierce media market, it must strengthen its core competitiveness, then meet new things with a correct attitude, and break through the bottleneck of development. Based on the comparison of the production capacity and brand influence of traditional media and emerging media, this paper puts forward the path of enhancing the core competitiveness of traditional media from the aspects of learning from new media, improving content productivity and expanding brand influence.
\end{abstract}

Keywords: enhancement, core values, competitiveness, traditional media, emerging media

\section{INTRODUCTION}

With the rapid development and strong expansion of new media, the advantages of traditional media are gradually lost in the competition. And its status has been challenged like never before, with most not optimistic about its viability. Then how to change the status quo to get out of trouble seems to have become a question to be reckoned with. In my opinion, the traditional media should take the initiative to deal with the changes in the new media era, to accurately locate the target readers, and to re-understand the content and methods of communication.

\section{COMPARISON OF ADVANTAGES AND DISADVANTAGES BETWEEN TRADITIONAL PAPER MEDIA AND NEW MEDIA}

\section{A. Advantages and disadvantages of traditional media}

1) Easy operation and low cost: Compared with the gorgeous appearance of new media, the simplicity of traditional media is also a kind of power. The traditional media, such as broadcasting, is still the most popular media because of its simple operation, low price and low cost.

2) Standards are more mature than new media: Traditional media, such as newspapers, television, radio, books and periodicals, have become very mature in the process of collection, editing, production, distribution and commercial operation. These professional resources are not available to most of the emerging media, and its huge and sophisticated professional talent chain is also impossible for new media to compete with it in a short period of time. Therefore, the specialization of traditional media is one of the valuable advantages.

3) Strict content audit and high-quality content: As we all know that content is the king craft forever. And high-quality content is the advantage of most traditional media. After many years of experience, the content of each kind of traditional media can only be transmitted through a strict process of inspection. Compared with the characteristics of new media content, the vast majority of high-quality content in the media market is still produced by traditional ones, and most of the excellent human resources related to this work in the traditional media, which is incomparable to the general media of network.

Of course, the paper media also has its unavoidable disadvantages. First of all, the speed is lagging. In today's speed winning society, if you want to occupy a position in the media industry where new media is rampant, speed is the short board of paper media. Secondly, the scope of traditional paper media is limited, and the coverage of traditional paper media is limited. Thirdly, the content form is single. The most attractive advantage of new media to the audience is the diversity of forms and the rich and diverse media information.

\section{B. Advantages of new media}

1) Meeting the diverse psychological and practical needs of the audience: Compared with traditional media, new media can greatly meet the needs of the audience. 
Taking the Internet as an example, the network provides people with a new way of behavior and communication, which makes people's psychology and behavior in network life have a great correlation and contrast with real society. This kind of connection and contrast can not only make people stay away from real society freely, but also let people integrate into the real society without boundaries. This is a rich world presented by the network, which can maximize the satisfaction of the diverse psychological and practical needs of the audience. What is particularly noteworthy is that the sense of spiritual satisfaction brought about by the Internet world is actually far greater than the socalled practical functions such as massive information, rapid retrieval and e-commerce. This sense of dependence is beyond the reach of traditional media.

2) Diverse interactions: In the process of information dissemination, reception and feedback, the new media, especially the network media, has changed the audience's spectator identity. The audience can search, receive, share and disseminate information on the media relatively freely, so as to meet the needs of the audience to participate in the information dissemination process. Therefore, the communication and interaction functions of many new media are carried out with the audience as the core, which is in sharp contrast to the traditional media's "everything from the perspective of the communicator". In the process of information dissemination, when the audience changes from passive position to active position, the audience's right of expression and participation will be more realized, and the forms of interaction will be more diversified.

3) New media has also had a great impact on people's lives: New media with powerful information frenzy, not only has an impact on information dissemination, but also has a great impact on human life, which is the most important reason that new media has been paid attention to. In the network media, people can realize personalized reading, listening and watching without being limited by time and place. They can not only receive information but also release information. They can shop, socialize, handle business and official affairs on the network, and enjoy many functions that other media can't realize. Once human life changes from demand to dependence, new media will have an unprecedented impact on human life.

\section{THE STRATEGY OF TRADITIONAL PAPER MEDIA TO DEAL WITH NEW MEDIA}

\section{A. Expanding the digital expression of traditional paper media}

The rapid development of new media has brought great crisis to traditional media, but also brought unprecedented opportunities and challenges. If the traditional media wants to gain a place, it must speed up the integration of the media. The digital expression of the traditional media can be the digital newspaper, micro magazine and other forms by using the network, mobile phone terminal and so on. In China, the central media was the first to set an example. In 2014, the editorial department of network was established with CCTV news as a pilot project. Guangming Daily and Microsoft jointly built a platform of media cloud, and launched cloud media and cloud newspaper reading. Local media groups at all levels also responded quickly and set up their own newspaper websites, such as the network TV launched by Zhejiang Daily, the website, and the mobile phone newspaper of daily of Chinese Women. In 2006, Guangzhou newspaper launched a product called "mobile phone flashy newspaper", which integrates videos, audios, animations and other media forms into one. The audience can get more information and media enjoyment from it. At the same time, mobile phone users can take photos of people and events around them and upload them to the mobile newspaper by using the function of photo taking of their mobile phones, so as to improve the audience's participation in the news and expand the coverage also enrich the sources of news.

\section{B. Paying attention to the actual content}

The authority of the content is very important for the paper media to remain invincible under the strong impact of new media. The paper media should take advantage of this advantage and expand to the depth and multi direction. First of all, we should be more indepth. The information of new media is overwhelming. People are easy to have fatigue and anxiety in the massive information. The paper media can excavate the depth of information, refine the news background and information, find out the route for the audience, and act as a guide for reading. Secondly, efforts should be made on localization. Newspapers and other paper media have an advantage in local news resources. This feature should be strengthened in order to win the support and support of local consumers. Thirdly, we should advance towards specialization. With the development and progress of the society, cultural level of audience is also constantly improving, and higher the requirements for the professionalism of news, the journalists should establish advanced concepts of news communication, be expert journalists, and adapt to the rapid development of the news industry. 


\section{Expanding living room}

In today's increasingly competitive media industry, the progress of science and technology has blurred the boundaries of various media. The use of diversified forms of business is an important way to improve the paper media's ability to fight. Foreign countries are one step ahead of China in this respect. Take the Chicago Tribune in the United States as an example. It mainly focuses on news and entertainment, involving newspapers, magazines, news broadcasting, television and network products. Due to the restrictions of policy, system and talents, China's diversified operation is not ideal, and there is monopoly operation, which is not effective for the expansion of other industries. The paper media should make use of the current vigorous development of new technology, use diversified forms to display themselves, expand diversified channels of business, and the content may win.

\section{Actively cooperating with new media}

The combination of network and station is the best way for the initial integration of traditional media and network media. Broadcast media can reflect the characteristics of massive information / first-time advantage / fast / wide coverage / high arrival rate, while network media can reflect the characteristics of mass information / depth / combination of video, audio and text / high retention of information / in line with the characteristics of communication development. Therefore, the initial integration of network media can be divided into two categories.

1) Horizontal expansion: Our broadcasting frequency can cooperate with well-known portal websites in an all-round way. Firstly, we can understand the live broadcast and on-demand broadcast of radio programs on the website. Secondly, we can realize the interaction of website / radio information and content, and then realize the cooperation of offline activities.

2) In-depth cooperation: According to key programs of radio frequency, close cooperation with multiple channels of the portal website can share media content, share audience, interact with each other, and jointly develop functional services, so as to truly achieve the combination of station and network sales.

\section{CONCLUSION}

In fact, multimedia integration is a peripheral view of the development of the media industry. Its essence is to base itself on its own innovation and development, take advantage of the new media, integrate resources, adjust the operating structure, and finally build a diversified media platform with traditional media as the mainstay. At the same time, in the development process of traditional media, it should adhere to its own advantages and incorporate its own development into the thinking of the chain of cultural industry so as to gain core competitiveness in the fierce competition, as well as realizing the establishment of an "information audience market" suitable for multiple communication channels with traditional media as the core.

\section{References}

[1] Yang Xiaohong. Adjust the operation and management mechanism to accelerate the integration of traditional broadcasting and new media, 2017 (12).

[2] Zheng Lin. Research on the innovation and development of traditional broadcasting under the influence of Internet. 2019 (10).

[3] Liu Yuanyuan. On the integration of traditional broadcasting media and new media. 2019 (10).

[4] Wu Pengfei. Discussion on the development path of traditional media and emerging media. 2019 (13).

[5] Lin Li. Talking about the choice of TV media and emerging media integration strategy. 2019(18).

[6] Zhang Yin. The cohesion and inheritance of public trust, and traditional media are duty bound $[\mathrm{N}]$. In the period of social transformation, various social contradictions have gradually emerged. People's daily of public opinion supervision, January 18,2011 